\title{
Thermal Stability Influence of the Enclosure Structure on the Building's Energy Efficiency
}

\author{
Daria Zaborova ${ }^{1,{ }^{*}}$, Marina Petrochenko ${ }^{1}$ and Ludmila Chernenkaya $^{1}$ \\ ${ }^{1}$ Peter the Great Saint-Petersburg Polytechnic University, 195251 Polytechnicheskaya str. 29, St. \\ Petersburg, Russia
}

\begin{abstract}
Thermal stability of the enclosure structures is one of the most important objective in the building design. Thermal processes in the wall depend not only on the internal and external air temperature, but also on many other factors. Therefore, complexity of this process make heat conservation in the room to be an actual problem. This paper presents dependence between thermal stability of the enclosure structure and its design. It was shown that thermophysical characteristics of materials directly affect the thermal processes in the wall. For the research, three frequently used types of enclosure structure in Russia were taken. For each wall was found the average temperature and cooling time. As a result, it was found that the higher values of thermal conductivity, specific heat and material density are, the higher average temperature of the wall is.
\end{abstract}

\section{Introduction}

Nowadays the problem of energy efficiency is one of the most discussed issues [1-5]. Especially for Russia, effective use of the fuel and natural resources is the main task. The main object of energy consumption is residential building. Approximately, energy consumption for heating buildings is about $40 \%$ of all extracted fuel [6]. The main energy task in the construction industry is design of buildings and constructions with effective use of energy [7, 8]. It is known that the biggest heat loss is through the walls. Therefore, much attention is paid to design the enclosure structures. Works of many people are devoted to the solution of this problem [9-13].

Operating principle of the enclosure structure is to keep heat in the house as long as possible [14-16]. For this reason, it is so important that material can be able to resist the stresses caused by change of temperature.

Thermophysical properties of structures and materials were investigated in works of G.M. Kondratyev, V. N. Bogoslovsky, G.N. Dulnev [17], Y. A. Tabunshchikov [18], A. S. Gorshkov $[19,20]$. These materials show the importance of heat transfer problem in structures.

\subsection{Purposes and objectives}

The purpose of the study is to establish the connection between the energy efficiency of the enclosure structure and its thermal stability. Thus, the following tasks have been set: 
1. To estimate dynamic of changes the average stationary temperature in multi-layer walls of different design;

2. To evaluate influence of thermal resistance on the enclosure structure average temperature.

\subsection{Research description}

Thanks to introduction of new rules for heat resistance of enclosure structures and increases cost of energy, in Russia is becoming more and more popular use of lightweight concrete in construction [21, 22]. In addition, such materials as reinforced concrete and brick do not maintain the requirements for thermal resistance any more. To compare what wall accumulates heat better we chose three different materials: lightweight concrete, brick and reinforced concrete.

For this study were selected three types of enclosure structure which are frequently used in construction (Fig. 1, 2, 3).

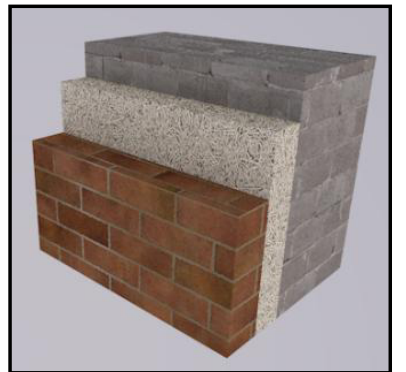

Fig. 1. Wall №1.

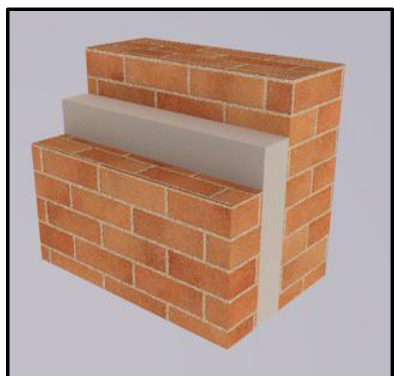

Fig. 2. Wall №2.

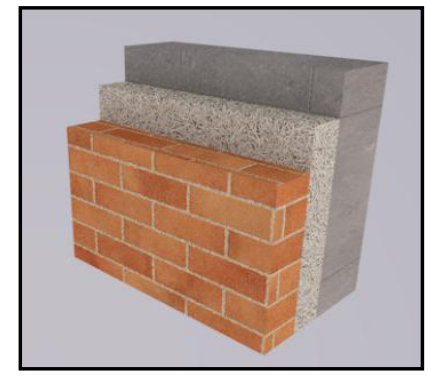

Fig. 3. Wall №3.

First type of the enclosure structure consists of three layers and has a total thickness 595 $\mathrm{mm}$ (Fig.4). The structure of the wall is shown below.

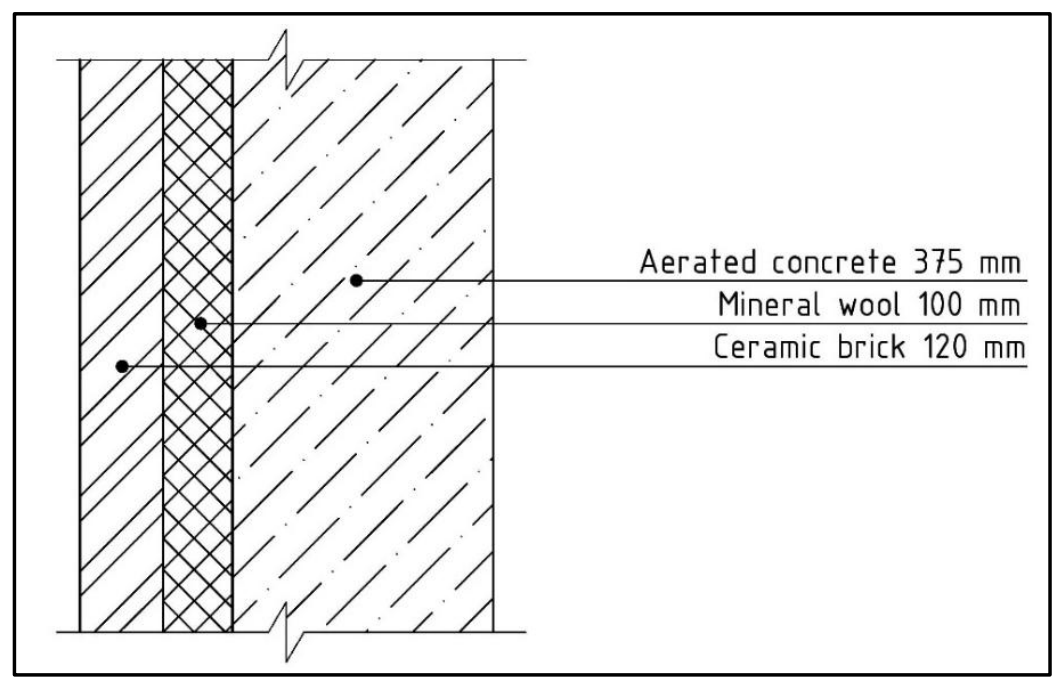

Fig. 4. The section view of the wall №1 by layers. Outdoor is on the left.

The thermal characteristics of materials are given in table 1 . 
Table 1. Thermal characteristics of materials.

\begin{tabular}{|c|c|c|c|c|c|c|}
\hline $\begin{array}{c}\text { № of } \\
\text { layer }\end{array}$ & \multirow{2}{*}{ Layer of material } & $\begin{array}{c}\text { Layer } \\
\text { thicknes } \\
\mathrm{s}, \\
\delta\end{array}$ & $\begin{array}{c}\text { Coefficient of } \\
\text { thermal } \\
\text { conductivity, } \\
\lambda\end{array}$ & $\begin{array}{c}\text { Specific } \\
\text { heat, } \mathrm{c}_{\mathrm{p}}\end{array}$ & $\begin{array}{c}\text { Density, } \\
\rho\end{array}$ & $\begin{array}{c}\text { Coefficient } \\
\text { of thermal } \\
\text { absorption, } \\
\beta\end{array}$ \\
\cline { 3 - 7 } & {$[\mathrm{m}]$} & {$\left[\mathrm{W} / \mathrm{m} \cdot{ }^{\circ} \mathrm{C}\right]$} & {$\left[\mathrm{J} / \mathrm{kg} \cdot{ }^{\circ} \mathrm{C}\right]$} & {$\left[\mathrm{kg} / \mathrm{m}^{3}\right]$} & {$\left[\mathrm{J} / \sqrt{\mathrm{s}} \cdot \mathrm{m}^{2} \cdot{ }^{\circ} \mathrm{C}\right]$} \\
\hline 1 & Aerated concrete & 0.375 & 0.14 & 1000 & 500 & 264.57 \\
\hline 2 & Mineral wool & 0.1 & 0.04 & 920 & 150 & 71.46 \\
\hline 3 & Ceramic brick & 0.12 & 0.64 & 880 & 1600 & 949.27 \\
\hline
\end{tabular}

Second type of the enclosure structure consists of three layers and has a total thickness $470 \mathrm{~mm}$ (Fig.5). The structure of the wall is shown below.

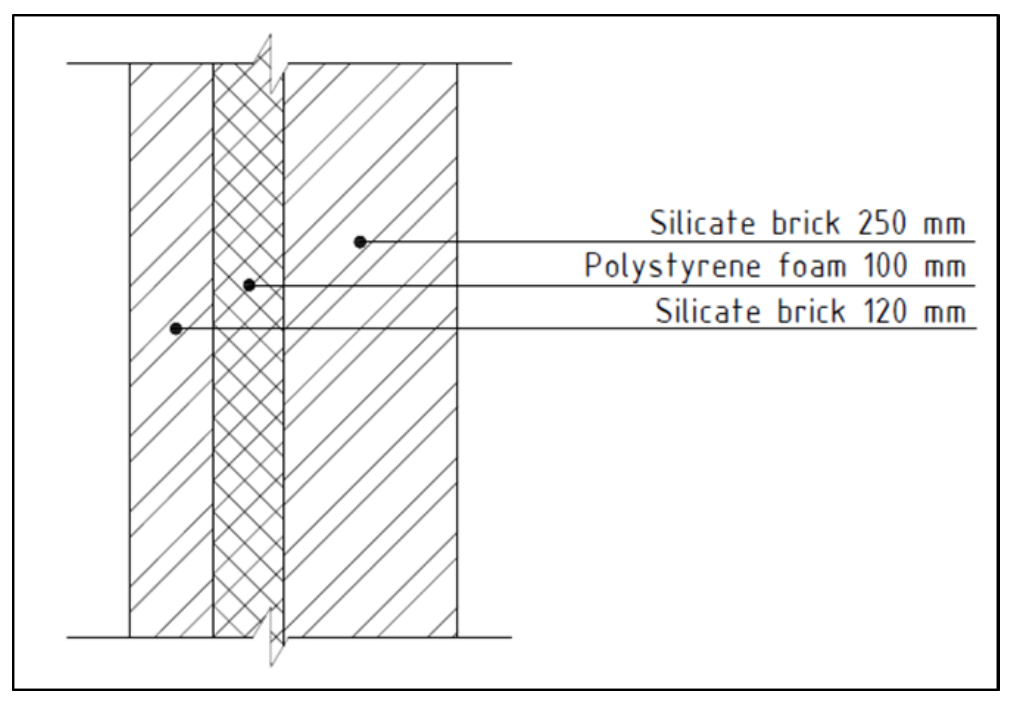

Fig. 5. The section view of the wall №2 by layers. Outdoor is on the left.

The thermal characteristics of materials are given in table 2.

Table 2. Thermal characteristics of materials.

\begin{tabular}{|c|c|c|c|c|c|c|}
\hline $\begin{array}{c}\text { № of } \\
\text { layer }\end{array}$ & Layer of material & $\begin{array}{c}\text { Layer } \\
\text { thickness, } \\
\delta\end{array}$ & $\begin{array}{c}\text { Coefficient of } \\
\text { thermal } \\
\text { conductivity, } \\
\lambda\end{array}$ & $\begin{array}{c}\text { Specific } \\
\text { heat, } \mathrm{c}_{\mathrm{p}}\end{array}$ & $\begin{array}{c}\text { Density, } \\
\rho\end{array}$ & $\begin{array}{c}\text { Coefficient } \\
\text { of thermal } \\
\text { absorption, } \\
\beta\end{array}$ \\
\cline { 2 - 7 } & {$[\mathrm{m}]$} & {$\left[\mathrm{W} / \mathrm{m} \cdot{ }^{\circ} \mathrm{C}\right]$} & {$\left[\mathrm{J} / \mathrm{kg} \cdot{ }^{\circ} \mathrm{C}\right]$} & {$\left[\mathrm{kg} / \mathrm{m}^{3}\right]$} & $\begin{array}{c}{\left[\mathrm{J} / \sqrt{\mathrm{s}} \cdot \mathrm{m}^{2} \cdot \circ\right.} \\
\mathrm{C}]\end{array}$ \\
\hline 1 & Silicate brick & 0.25 & 0.81 & 800 & 1500 & 985.90 \\
\hline 2 & Polystyrene foam & 0.10 & 0.04 & 1340 & 150 & 89.67 \\
\hline 3 & Silicate brick & 0.12 & 0.81 & 800 & 1500 & 985.90 \\
\hline
\end{tabular}

Third type of the enclosure structure consists of three layers and has total thickness 470 $\mathrm{mm}$ (Fig.6). The structure of the wall is shown below. 


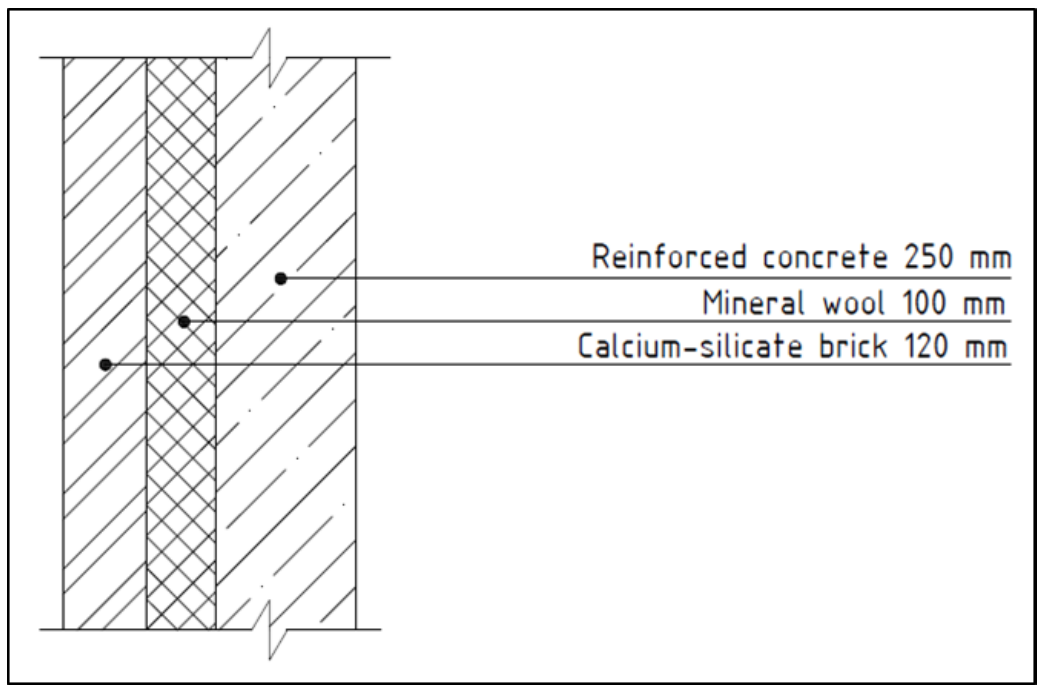

Fig. 6. The section view of the wall №3 by layers. Outdoor is on the left.

The thermal characteristics of materials are given in table 3.

Table 3. Thermal characteristics of materials.

\begin{tabular}{|c|c|c|c|c|c|c|}
\hline $\begin{array}{c}\text { № of } \\
\text { layer }\end{array}$ & Layer of material & $\begin{array}{c}\text { Layer } \\
\text { thickness, } \\
\delta\end{array}$ & $\begin{array}{c}\text { Coefficient of } \\
\text { thermal } \\
\text { conductivity, } \\
\lambda\end{array}$ & $\begin{array}{c}\text { Specific } \\
\text { heat, } \mathrm{c}_{\mathrm{p}}\end{array}$ & $\begin{array}{c}\text { Density, } \\
\rho\end{array}$ & $\begin{array}{c}\text { Coefficient } \\
\text { of thermal } \\
\text { absorption, } \\
\beta\end{array}$ \\
\cline { 3 - 7 } & {$[\mathrm{m}]$} & {$\left[\mathrm{W} / \mathrm{m}^{\circ} \mathrm{C}\right]$} & {$\left[\mathrm{J} / \mathrm{kg} \cdot{ }^{\circ} \mathrm{C}\right]$} & {$\left[\mathrm{kg} / \mathrm{m}^{3}\right]$} & {$\left[\mathrm{J} / \sqrt{\mathrm{s}} \cdot \mathrm{m}^{2} \cdot{ }^{\circ} \mathrm{C}\right]$} \\
\hline 1 & $\begin{array}{c}\text { Reinforced } \\
\text { concrete }\end{array}$ & 0.25 & 1.70 & 840 & 2500 & 1889.44 \\
\hline 2 & Mineral wool & 0.1 & 0.04 & 920 & 150 & 74.30 \\
\hline 3 & Silicate brick & 0.12 & 0.81 & 880 & 1600 & 1067.93 \\
\hline
\end{tabular}

Internal coefficient of heat transfer $\alpha_{\text {int }}, \mathrm{W} /\left(\mathrm{m}^{2} \cdot{ }^{\circ} \mathrm{C}\right)$ demonstrates the ability of material to absorb heat when temperature fluctuates on its surface and can be found by the formula:

$$
\alpha_{\text {int }}=\sqrt{\frac{\lambda \cdot \rho \cdot c_{p}}{t_{0}}},
$$

where $t_{0}$ - fluctuation period of a thermal steam, $s$;

$\beta=\sqrt{\lambda \cdot \rho \cdot c_{p}}$ - coefficient of thermal absorption, $J /\left(\sqrt{s} \cdot \mathrm{m}^{2} \cdot{ }^{\circ} \mathrm{C}\right)$.

Thus, the heat absorption of construction depends on physical properties of material.

\section{Calculations of the wall average temperature}

Because the multilayer walls consist of different layers, the coefficients $\lambda, \rho, c_{p}$ are changed discretely. With great number of layers, the discrete distribution can be replaced by a continuous distribution, and from summation turn to integration of continuous distributions. 


$$
\mathrm{R}=\sum \frac{\delta_{\mathrm{i}}}{\lambda_{\mathrm{i}}}=\int_{0}^{\delta} \frac{\mathrm{dx}}{\lambda(\mathrm{x})}
$$

where $\mathrm{R}$ wall heat transfer resistance, $\left(\mathrm{m}^{2} \cdot{ }^{\circ} \mathrm{C}\right) / \mathrm{W}$.

We determined the average stationary temperature for each type of wall by the formula:

$$
\mathrm{T}_{\infty}=\frac{\alpha_{\mathrm{c}} \cdot \mathrm{T}_{\mathrm{c}}+\alpha_{\mathrm{h}} \cdot \mathrm{T}_{\mathrm{h}} \cdot\left(1+\alpha_{\mathrm{c}} \cdot \int_{0}^{\delta} \frac{\mathrm{dx}}{\lambda(\mathrm{x})}\right)}{\alpha_{\mathrm{c}}+\alpha_{\mathrm{h}} \cdot\left(1+\alpha_{\mathrm{c}} \cdot \int_{0}^{\delta} \frac{\mathrm{dx}}{\lambda(\mathrm{x})}\right)}+\frac{\alpha_{\mathrm{c}} \cdot \alpha_{\mathrm{h}} \cdot\left(\mathrm{T}_{\mathrm{h}}-\mathrm{T}_{\mathrm{c}}\right)}{\alpha_{\mathrm{c}}+\alpha_{\mathrm{h}} \cdot\left(1+\alpha_{\mathrm{c}} \cdot \int_{0}^{\delta} \frac{\mathrm{dx}}{\lambda(\mathrm{x})}\right)} \cdot \frac{1}{\delta} \cdot \int_{0}^{\delta} \frac{(\delta-\xi) \mathrm{d} \xi}{\lambda(\xi)}
$$

where $\alpha_{\mathrm{c}}=23 \mathrm{~W} /\left(\mathrm{m}^{2} \cdot{ }^{\circ} \mathrm{C}\right)$ - outer surface heat transfer coefficient of the building envelope; $\alpha_{\mathrm{h}}=8.7 \mathrm{~W} /\left(\mathrm{m}^{2} \cdot{ }^{\circ} \mathrm{C}\right)$ - inner surface heat transfer coefficient of the building envelope;

$\mathrm{T}_{\mathrm{h}}$ - the internal air temperature in the premises of a residential building in St. Petersburg, taken in accordance with GOST 30494 at $20^{\circ} \mathrm{C}$;

$\mathrm{T}_{\mathrm{c}}$ - the average monthly outdoor air temperature in January, taken in accordance with SNIP 23-01-99* at $-8.7^{\circ} \mathrm{C}$;

$\delta$ - thickness of the wall, $\mathrm{m}$;

$\lambda$ - thermal conductivity, $\mathrm{W} /\left(\mathrm{m} \cdot{ }^{\circ} \mathrm{C}\right)$. The calculation results are summarized in Table 4 .

Table 4. Average temperature of enclosure structure.

\begin{tabular}{|c|c|c|c|}
\hline $\begin{array}{c}\text { Average stationary } \\
\text { temperature }\end{array}$ & Sample №1 & Sample №2 & Sample №3 \\
\hline $\mathrm{T}_{\infty},{ }^{\circ} \mathrm{C}$ & 5.22 & 8.34 & 8.89 \\
\hline
\end{tabular}

Calculations have shown that the wall with the highest thermal conductivity has the highest average temperature. Influence of wall heat conductivity on its average temperature is shown in Figure 7.

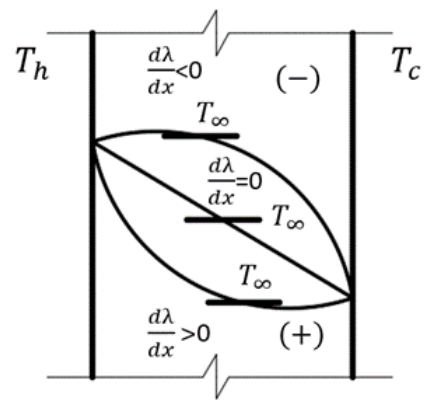

Fig. 7. Dependence of average temperature on heat conductivity coefficient.

Now we determine the instantaneous average temperature of the wall:

$$
\overline{\mathrm{T}}=\left(\mathrm{T}_{\mathrm{h}}-\mathrm{T}_{\infty}\right) \cdot \theta+\mathrm{T}_{\infty} .
$$

Temporary measure of thermal stability - $\theta$ can be found by the formula (4).

$$
\theta=\exp \left(-\frac{\mathrm{t}}{\mathrm{t}_{\mathrm{h}}}-\frac{\mathrm{t}}{\mathrm{t}_{\mathrm{c}}}\right)
$$




\section{TPACEE-2016}

where $\mathrm{t}$ - cooling time of the wall, $\mathrm{s}$.

The value of $t_{h}$ and $t_{c}$ were determined from the following equations:

$$
\begin{gathered}
\mathrm{t}_{\mathrm{h}}=\frac{\rho \cdot \mathrm{c}_{\mathrm{p}} \cdot \delta}{\alpha_{\mathrm{h}}}, \\
\mathrm{t}_{\mathrm{c}}=\frac{\rho \cdot \mathrm{c}_{\mathrm{p}} \cdot \delta}{\alpha_{\mathrm{c}}} .
\end{gathered}
$$

The results of calculation for each construction type are summarized in table 5 .

Table 5. Instantaneous average temperature.

\begin{tabular}{|c|c|c|c|c|c|c|c|}
\hline $\begin{array}{c}\text { Time, } \\
\text { hours }\end{array}$ & Wall № 1 & Wall № 2 & Wall № 3 & $\begin{array}{c}\text { Time, } \\
\text { hours }\end{array}$ & Wall № 1 & Wall № 2 & $\begin{array}{c}\text { Wall } \\
\text { № 3 }\end{array}$ \\
\hline 0 & 20 & 20 & 20 & 13 & 6.26 & 9.18 & 9.98 \\
\hline 1 & 17.27 & 17.86 & 18.18 & 14 & 6.07 & 9.03 & 9.80 \\
\hline 2 & 15.04 & 16.12 & 16.66 & 15 & 5.91 & 8.90 & 9.65 \\
\hline 3 & 13.23 & 14.69 & 15.39 & 16 & 5.78 & 8.80 & 9.53 \\
\hline 4 & 11.75 & 13.53 & 14.33 & 17 & 5.68 & 8.71 & 9.42 \\
\hline 5 & 10.54 & 12.58 & 13.44 & 18 & 5.59 & 8.64 & 9.33 \\
\hline 6 & 9.56 & 11.80 & 12.70 & 19 & 5.53 & 8.59 & 9.26 \\
\hline 7 & 8.76 & 11.17 & 12.07 & 20 & 5.47 & 8.54 & 9.20 \\
\hline 8 & 8.10 & 10.65 & 11.55 & 21 & 5.42 & 8.51 & 9.15 \\
\hline 9 & 7.57 & 10.22 & 11.12 & 22 & 5.39 & 8.48 & 9.11 \\
\hline 10 & 7.10 & 9.88 & 10.75 & 23 & 5.35 & 8.45 & 9.07 \\
\hline 11 & 6.78 & 9.59 & 10.45 & 24 & 5.33 & 8.43 & 9.04 \\
\hline 12 & 6.5 & 9.37 & 10.19 & & & & \\
\hline
\end{tabular}

Time-average temperature transformation in all free types of enclosure structure are presented in Figure 8.

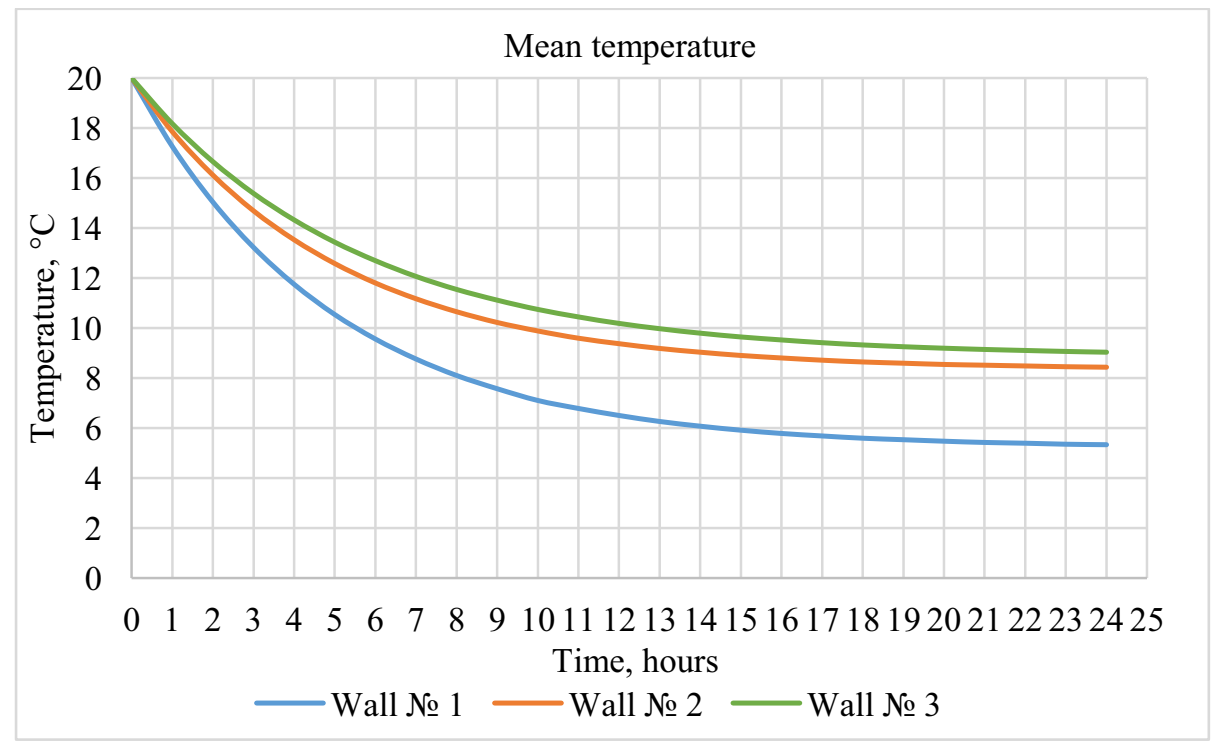

Fig. 8. Cooling time of the walls. 


\section{Conclusions}

1. The results of calculations showed that reinforced concrete wall has the highest average temperature $8.89^{\circ} \mathrm{C}$. The aerated concrete wall has the lowest average temperature $5.22{ }^{\circ} \mathrm{C}$. These values confirm that wall with big coefficient of thermal absorption $\beta$ has a higher average temperature than wall with small coefficient of thermal absorption.

2. Aerated concrete wall cools much faster than wall made from brick or reinforced concrete.

3. Heat accumulation is very important for energy saving and creation the optimal climate in the house. However, despite the small coefficient of thermal conductivity $\lambda$, heat storage capacity of aerated concrete is less than in reinforced concrete wall.

From the standpoint of energy efficiency, reinforced concrete wall is unreasonable. However, from the standpoint of thermostability this is reasonable wall.

\section{References}

1. V. Murgul, JAES, 12 (1), 1-10, (2014)

2. M.V. Knat'ko, M.N. Efimenko, A.S. Gorshkov, MCE, 2, 50-53, (2008)

3. D. Nemova, V. Murgul, A. Golik, E. Chizhov, V. Pukhkal, N. Vatin, JAES, 12 (1), $37-$ 44, (2014)

4. A. Gorshkov, N. Vatin, D. Nemova, A. Shabaldin, L. Melnikova, K. Paramonov, Procedia Eng., 117, 1080-1089, (2015)

5. L. Svatovskaya, A. Sychova, M. Sychov, V. Okrepilov, MATEC Web of Conferences, 53, Article Number 01023 (2016)

6. E. Perlova , S. Karpova, X. Rakova, E. Bondarenko, M. Platonova, A. Gorshkov, AMM, 725-726, 1580-1588, (2015)

7. A. Lupíšek, M. Bureša, M. Volfa, J. Hodkováa, J. Nováčeka, P. Hejtmáneka, J. Tywoniak, Energy Procedia, 78, 285-290, (2015)

8. J. Tywoniak, K. Sojková, Energy Procedia, 78, 1069-1074, (2015)

9. D.V. Petrosova, N.M. Kuz'menko, D.V. Petrosov, MCE, 8, 31-37, (2013)

10. E. Kossecka, J. Kosny, J. Therm. Envelope Build. Sci., 7, 721-731, (1998)

11. S.V. Korniyenko, MCE, 8, 25-37, (2014)

12. J. Carmeliet, H. Hens, C. Vermeir, Research in building physics, (2003)

13. Medved, A. Trnik, Thermophysics and Mass Transfer in Materials Science and Construction, (2015)

14. M. R. Hall, Materials for energy efficiency and thermal comfort in buildings, (2010)

15. S. Kubba, Green building design and construction, (2012)

16. P. Glover, Building surveys 7 edition, (2008)

17. G.N. Dul'nev, D.P. Volkov, V.I. Malarev, V.I. Malarev, J. Eng. Phys. Thermophys., 56 (2), 198-206, (1989)

18. G.P. Vasilyev, V.A. Lichman, M.V. Kolesova, N.V. Peskov, M.M. Brodach, Y. A. Tabunshchikov, Energy Build., 86, 803-807, (2015)

19. N.I. Vatin, A.S. Gorshkov, D.V. Nemova, A. A. Staritcyna, D. S. Tarasova, Adv. Mater. Res., 941-944, 905-920, (2014)

20. N.I. Vatin, D.V. Nemova, P.P. Rymkevich, A.S. Gorshkov, MCE, 8, 4-14, (2013)

21. A.S. Gorshkov, P.P. Rymkevich, N.I. Vatin, MCE, 8, 38-48, (2014)

22. N.I. Vatin, A.S. Gorshkov, D.V. Nemova, Constr. of Unique Build. and Str. 3 (8), 1$11,(2013)$ 